\title{
Psychological distress in applicants for predictive DNA testing for autosomal dominant, heritable, late onset disorders
}

Departments of Medical Psychology and Psychotherapy, Erasmus University Rotterdam, PO Box 1738, 3000 DR Rotterdam, The

Netherlands

A C DudokdeWit

A Tibben

H J Duivenvoorden

P G Frets

M W Zoeteweij

J Passchier

Department of Clinical Genetics, Erasmus University and

University Hospital

Dijkzigt, State

University Leiden, The

Netherlands

A Tibben

P G Frets

M F Niermeijer

Department of Clinical Genetics, University Hospital Leiden, The Netherlands

A C Dudok de Wit

$M$ W Zoeteweij

$M$ Losekoot

A van Haeringen

Correspondence to: Dr DudokdeWit.

Received 29 August 1996 Revised version accepted for publication 3 January 1997

\author{
A C DudokdeWit, A Tibben, H J Duivenvoorden, P G Frets, M W Zoeteweij, \\ M Losekoot, A van Haeringen, M F Niermeijer, J Passchier, and the other members of the \\ Rotterdam/Leiden Genetics Workgroup*
}

\begin{abstract}
*Participating in the Rotterdam/Leiden Genetics Workgroup are, besides the authors already mentioned: D Lindhout, E J Meijers-Heijboer, Department of Clinical Genetics, Rotterdam; L N Lodder, R W Trijsburg, Department of Medical Psychology and Psychotherapy, Rotterdam; J G M Klijn, "Daniel den Hoed" Cancer Centre, Rotterdam; A Bröcker-Vriends, A T J M Helderman, Y Hilhorst-Hofstee, S Kant, J A Maat-Kievit, J C Oosterwijk, J J van der Smagt, M Vegter-van der Vlis, M-A C S Vries-van der Weerd, Department of Clinical Genetics, Leiden; E Bakker, C J Cornelisse, P Devilee, C Tops, Department of Human Genetics, Leiden; H F A Vasen, Dutch Foundation of Hereditary Tumours (STOET), Leiden, The Netherlands.
\end{abstract}

Abstract

In a comparative study on the effects of predictive DNA testing for late onset disorders, pre-test psychological distress was assessed in people at risk for Huntington's disease (HD, $n=41$ ), cerebral haemorrhage (HCHWA-D, $n=9$ ), breast and ovarian cancer (HBOC, $n=24)$, and polyposis coli (FAP, $n=45$ ). Partners, if available, also participated in the study. Distress was measured with the subscales Intrusion and Avoidance of the Impact of Event Scale.

People at risk for the neurodegenerative disorders reported more avoidance than those at risk for the cancer syndromes. People at risk for FAP and partners of those at risk for $\mathrm{HBOC}$ reported less intrusion than the others at risk and the other partners. Subjects who were more distressed reported more experiences with the disease in close relatives, the disease having a great impact on their lives, having considerations against predictive testing, expecting that being identified as a gene carrier would have adverse effects, and expecting relief after being identified as a non-carrier. Test candidates who expected an increase of personal problems showed higher avoidance, whereas those who could better anticipate future life as a carrier had higher intrusion levels.

Generally, subjects with high distress levels are of more concern to the healthcare professional than those with low distress levels. However, high distress may reflect worrying as a mental preparation for the test result, whereas low distress may indicate denial-avoidance behaviour and poor anticipation of the test outcome. In pre-test counselling sessions, this should be acknowledged and addressed. (f Med Genet 1997;34:382-390)

Keywords: predictive DNA testing; pre-test psychological distress; hereditary neurodegenerative disorders; hereditary cancer syndromes
The rapid developments in molecular genetics has made predictive testing by linkage analysis and direct mutation analysis possible for a growing number of neurodegenerative disorders (for example, Huntington's disease (HD), myotonic dystrophy (MD), hereditary cerebral haemorrhages with amyloidosis-Dutch type (HCHWA-D), familial Alzheimer's disease) $)^{1-5}$ and cancer syndromes (for example, hereditary breast and ovarian cancer (HBOC), familial adenomatous polyposis (FAP), hereditary nonpolyposis colonic cancer (HNPCC))..$^{6-10}$ Informativeness and reliability of predictive testing is increasing and, as techniques become widely available, testing will be offered by an increasing number of institutes. Methods for familial genetic studies and counselling of people requesting testing will be essential in every programme. More knowledge about the implications of predictive testing is also needed by society, in order to be able to decide upon the appropriate uses to which predictive testing may be put and about any controls that might be deemed necessary. ${ }^{11}$

Predictive testing for HD has been suggested to be a useful paradigm for the study of other late onset disorders, such as cancer syndromes (for example, HBOC, FAP, HNPCC). ${ }^{12}$ The similarities between $\mathrm{HD}$ and these hereditary cancer syndromes are autosomal dominant inheritance, the onset of a variety of symptoms with increasing age, and major impact on the family. The cancer syndromes differ, however, from HD by absence of neuropsychiatric symptoms and the availability of choices for treatment. ${ }^{13}$ Study is needed as to what extent the experiences with presymptomatic testing for HD can be generalised to other dominant, heritable, late onset disorders, such as cancer syndromes.

Experience so far indicates that, as for $\mathrm{HD},{ }^{14-16}$ the uptake of the predictive DNA test for $\mathrm{HBOC}$ has been lower than expected. ${ }^{17}$ Although a higher uptake of the test has been reported for the cancer syndromes in The Netherlands, so far $26 \%$ of those at risk for FAP have taken the test (STOET, personal 
Table 1 Autosomal dominant neurological disorders and cancer syndromes in The Netherlands, as included in the study

\begin{tabular}{|c|c|c|c|c|}
\hline & $H D^{5358}$ & $H C H W A-D^{54}$ & $F A P^{s s}$ & $\begin{array}{l}H B O C \text { (caused by the BRCA1 } \\
\text { gene) })^{59-61}\end{array}$ \\
\hline Age of onset & $40 \pm 12$ years & $40-65$ years & From 12 years onwards & From 25 years onwards \\
\hline Disease characteristics & $\begin{array}{l}\text { Involuntary movements, } \\
\text { changes in behaviour and } \\
\text { personality, cognitive } \\
\text { impairment }\end{array}$ & $\begin{array}{l}\text { Acute occurrence of headache, } \\
\text { nausea, and focal neurological } \\
\text { deficits with or without loss of } \\
\text { consciousness }\end{array}$ & $\begin{array}{l}\text { Development of numerous (at } \\
\text { least } 100 \text { ) colorectal polyps } \\
\text { and multiple extracolonic } \\
\text { symptoms }\end{array}$ & $\begin{array}{l}\text { Breast and ovarian cancer for } \\
\text { women, possible colonic cancer } \\
\text { for both men and women, } \\
\text { possible prostatic carcinoma for } \\
\text { men }\end{array}$ \\
\hline $\begin{array}{l}\text { Duration of the illness } \\
\text { without treatment }\end{array}$ & \pm 15 years & Variable $^{\star}$ & $\begin{array}{l} \pm 4 \text { years after manifest } \\
\text { malignancy }\end{array}$ & $\begin{array}{l} \pm 2 \text { years after manifest } \\
\text { malignancy }\end{array}$ \\
\hline Surveillance & - & - & $\begin{array}{l}\text { Colonoscopy, sigmoidoscopy, } \\
\text { rectoscopy }\end{array}$ & $\begin{array}{l}\text { Breast examination, palpation, } \\
\text { mammography, ultrasound } \\
\text { screening, etc }\end{array}$ \\
\hline Treatment & - & - & Colectomy & $\begin{array}{l}\text { (Prophylactic) } \\
\text { mastectomy/oophorectomy }\end{array}$ \\
\hline $\begin{array}{l}\text { Degree of penetrance } \\
\text { Predictive DNA testing }\end{array}$ & $100 \%$ (lifetime) & $100 \%$ (by age 60 ) & $100 \%$ (by age 40 ) & $95 \%$ (lifetime) \\
\hline Linkage analyses since: & 1987 & 1991 & 1989 & 1994 \\
\hline Mutation analyses since: & 1993 & 1991 & 1991 & 1995 \\
\hline Frequency & \pm 3100 at risk & \pm 400 at risk & 536† at risk & - \\
\hline Incidence & - & 一 & - & \pm 750 new patients each year \\
\hline Uptake & \pm 490 tested & \pm 45 tested & $193+$ tested & \pm 120 tested \\
\hline
\end{tabular}

$\mathrm{HD}=$ Huntington's disease, HCHWA-D=hereditary cerebral haemorrhages with amyloidosis-Dutch type, FAP=familiar adenomatous polyposis. HBOC=hereditary breast and ovarian cancer.

*Two-thirds of the patients die as a consequence of their first stroke: in the remaining patients neurological deficits depending on the location of the lesions modify the clinical picture.

†Registered with the Dutch Foundation of Hereditary Tumours (STOET). It is estimated that there are still five or six families not registered and new cases do occur, owing to new mutations.

communication) in The Netherlands, while in Rotterdam $33 \%$ of those at risk for $\mathrm{HBOC}$ have been tested (L N Lodder, E J MeijersHeijboer, personal communication). It is estimated that in The Netherlands about $15 \%$ of people at risk for $\mathrm{HD}^{18}$ and about $10 \%$ of those at risk for HCHWA-D ${ }^{19}$ have been presymptomatically tested. Those coming for the test are considered to be a selection who believe that they are better equipped to handle "bad news" and have considerable mental resources. ${ }^{20} 21$ Those not taking the test had a significantly more pessimistic outlook on themselves and their futures..$^{22}$ Reasons for being tested were to end uncertainty, to have some control over the future (planning future life and family), and to give information to offspring and relatives. ${ }^{23-27}$ Those at risk for the cancer syndromes reported the same reasons for wanting the test, with additional mention of the preventive treatment options. ${ }^{28}$

The consequences of predictive testing for the family have been shown in limited studies so far. Personal stories and case descriptions, however, have indicated that hereditary disease has a profound impact on the family. ${ }^{29-31}$ Furthermore, partners of identified carriers felt burdened by the distressing prospect, ${ }^{32-35}$ and more so when they had children. ${ }^{36}$

Clinical and empirical evidence has shown that potentially traumatic events may produce psychological symptoms. ${ }^{37}$ Alternating phases of experiencing intrusive feelings and avoidance of certain ideas and thoughts associated with the specific traumatic event are often seen in maladaptive reactions to such stressors. ${ }^{38}$ The stress response theory of Horowitz et a ${ }^{39}$ and our observations on people at risk and their families leads to the expectation that post-test adjustment involves (re)experiencing untoward intrusive feelings and thoughts and denial-avoidance of situations associated with the specific hereditary disease. On the other hand, intrusive feelings may reflect worrying as psychological anticipation of a threatening event, ${ }^{40}$ which can be useful in preparation for the test outcome.

The present study aimed to gain insight into reported pre-test psychological distress in terms of preparation for the test result. The first question addressed was whether the pre-test psychological distress in participants in predictive testing for HD, HCHWA-D, FAP, and $\mathrm{HBOC}$ would differ, and the same was assessed for partners. The second question was whether the psychological distress experienced could be predicted by the experience with the disorder in the family, that is, with the affected parent/relatives. The third question was whether the motivation to be tested predicted pre-test psychological distress and, finally, whether the expected impact of the test result predicted pre-test psychological distress.

This study is a part of a longitudinal follow up study on predictive testing focusing on: (1) the course of adjustment of subjects at risk and their partners after the DNA test results, and (2) identification of psychological determinants of adjustment problems after test disclosure. The aim is to increase the understanding of the psychological ramifications of predictive testing for late onset disorders, in order to develop counselling and support strategies.

\section{Subjects and methods}

SELECTION OF GENETIC DISORDERS IN THIS STUDY (TABLE 1)

All neurological and cancer syndromes in this study show autosomal dominant inheritance. All participants at risk for $\mathrm{HD}$ in this study received their test result by direct mutation testing, giving a reliability of $>99 \% .^{14142}$ All participants at risk for HCHWA-D could also be offered direct mutation testing, giving a reliability of $>99 \%$. $^{5}$

Predictive testing for FAP is performed in a stepwise fashion. First an index patient is screened for the presence of a mutation, ${ }^{434}$ so the family members can be offered direct mutation testing. In about one third of the 
families no mutation is found. In this case, when the family structure is appropriate, linkage analysis can be attempted. In this study, four participants at risk for FAP were offered presymptomatic testing by linkage analysis with a reliability varying from $95-99 \%$. In this study, all participants at risk for $\mathrm{HBOC}$ could be offered direct mutation testing for the BRCA1 gene. ${ }^{45} 46$

PARTICIPANTS

Predictive DNA testing and psychological follow up was offered to subjects aged 18 years and over at $50 \%$ risk. The inclusion criteria for the psychological study were an ability to give informed consent and adequate understanding of the questionnaires. Between 1 September 1993 and 31 August 1995, 149 subjects at risk for HD $(n=47)$, HCHWA-D $(n=12)$, FAP $(n=60)$, and HBOC $(n=30)$ who met the criteria were asked to participate in the psychological study. Partners were also invited to join the study. Nine at risk subjects withdrew from the predictive testing procedure. Thirteen subjects at risk (10 of them for FAP) opted for the DNA test but decided against the psychological study. Another six, who initially consented to participate, did not return their pre-test questionnaires. In total, 121 people at risk and 80 partners entered the study.

\section{PROCEDURES}

Information about the availability of the DNA test was given either by the general practitioner, neurologist, oncologist, clinical genetic service, relatives, or one of the respective patient organisations. Families who did participate in the research phase for linkage or mutation testing or both of the cancer syndromes were informed about the possibility of predictive testing by the Department of Clinical Genetics in Leiden and Rotterdam, or by the Dutch Foundation for Hereditary Tumours (STOET). Information from the public media made a number of participants aware of the autosomal dominant inheritance of the disorders in their family.

The study protocol was adapted from the HD protocol. ${ }^{47}$ The genetic counselling and the psychological study were conducted at the Departments of Clinical Genetics of the University Hospital Leiden and of the University Hospital Dijkzigt Rotterdam from September 1993. Two pre-test and two post-test sessions were held with a psychologist (ACDdW). At the first appointment at the Department of Clinical Genetics the psychological study was introduced. Subsequently, psychological self-report inventories were given to both the participants at risk and their partners.

The psychological questionnaires given at the pre-test interview to the participants at risk and their partners included the Impact of Event Scale (IES) and the Attitude Questionnaire (AQ) (see below).

\section{QUESTIONNAIRES}

The IES classifies the effects of stress into two major categories: intrusion and avoidance.
Intrusion refers to intrusively experienced ideas, images, feelings, or bad dreams. Avoidance refers to consciously recognised avoidance of certain ideas, feelings, or situations. ${ }^{39} 48$ It is a reliable, self-report scale that can be anchored to any specific life event. It permits assessment of people over time, comparison of the degree of distress between subgroups, and comparison of the impact of various life events. ${ }^{49}$ We anchored it to HD, HCHWA-D, FAP, and HBOC.

The IES consists of seven items that form the intrusion subscale (score range $0-35$, with a higher score indicating more intrusion) and eight items that underlie the avoidance subscale (score range $0-40$, with a higher score indicating more avoidance).

An Attitude Questionnaire (AQ) was used, consisting of 15 questions covering three areas: (A) experience of the disorder, (B) motivation for the test, and $(C)$ expected impact of the test result. Seven questions were open ended and nine were multiple choice. Answer categories were compiled to accommodate the common themes emerging from the responses on the open ended questions.

(A) Experience with the disorder was assessed by the following data: the age of learning about the hereditary nature of the disorder in the family, the event that prompted this information to be given, the number of affected family relatives, the most significant recollections about the affected parent and other relatives, the age they learned about their own risk, and the effect of the disease on their life until now.

(B) The motivation to be tested was assessed by asking participants and their partners about their considerations for and against testing.

(C) The expected impact of the test result was assessed by the following data. Statement questions were asked (to answer with "agree", "don't know", or "disagree") regarding the future when proven to be a gene carrier: life will become less worthwhile, problems will increase, will try to keep away from my family, will be better able to plan the future, will become depressive, the problems and worries for partner will increase, it will have a negative effect on marriage/relationship, problems for children will increase, and will be better able to plan the future for wife and children; whether they expected that their future might differ from their actual life; whether they would doubt the test result when proven to be a gene carrier.

Similar questions on the expected impact of being a non-gene carrier were posed. Participants were asked to respond with "agree", "don't know", or "disagree" to the following statements: life will become more worthwhile, problems will decrease, will try to keep away from my family, will be better able to plan the future, mood will improve, the problems and worries for partner will decrease, will have a positive effect on marriage/relationship, problems for children will decrease, and will be better able to plan the future for wife and children. Further, they were asked whether they expected their future to differ from their actual 
Table 2 Pretest characteristics of participants at risk

\begin{tabular}{|c|c|c|c|c|c|c|c|}
\hline & $H D(n=42)$ & $\begin{array}{l}H C H W A-D \\
(n=10)\end{array}$ & $F A P(n=45)$ & $H B O C(n=24)$ & Statistic & $d f$ & $p$ \\
\hline Male/female at risk & $15 / 27$ & $4 / 6$ & $22 / 23$ & $5 / 19$ & & & \\
\hline Age $(y)$, mean (SD) & $37.1(10.9)$ & $35.1(16.4)$ & $29.8(11.5)$ & $41.3(11.6)$ & $F=5.68$ & 3,116 & 0.01 \\
\hline $\begin{array}{l}\text { Age (y) learned about the disorder in the } \\
\text { family, mean (SD) }\end{array}$ & $25.8(14.9)$ & $25.6(4.2)$ & $17.9(11.6)$ & $27.9(15.2)$ & $\mathrm{F}=1.12$ & 3,115 & 0.35 \\
\hline $\begin{array}{l}\text { Age (y) learned about being at risk, mean } \\
\text { (SD) } \\
\text { Married/common law No }(\%) \\
\text { Child(ren) No }(\%)\end{array}$ & $\begin{array}{l}28.8(15.2) \\
31(74) \\
21(50)\end{array}$ & $\begin{array}{l}26.3(4.9) \\
8(80) \\
8(80)\end{array}$ & $\begin{array}{l}20.1(19.6) \\
19(43) \\
16(36)\end{array}$ & $\begin{array}{l}33.5(12.6) \\
22(92) \\
21(87.5)\end{array}$ & $\begin{array}{l}\mathrm{F}=3.79 \\
\chi^{2}=19.89 \\
\chi^{2}=24.2\end{array}$ & $\begin{array}{l}3,115 \\
3 \\
6\end{array}$ & $\begin{array}{l}0.02 \\
0.001 \\
0.15\end{array}$ \\
\hline
\end{tabular}

df, F, $\chi^{2}$, see text for details. $n=$ number of persons.

Table 3 Intrusion and avoidance in the four groups of at risk participants and their partners

\begin{tabular}{|c|c|c|c|c|c|c|c|c|c|c|c|}
\hline \multirow[b]{3}{*}{ Variable } & \multicolumn{11}{|l|}{ At risk } \\
\hline & \multicolumn{2}{|c|}{$H D(n=41)$} & \multicolumn{2}{|c|}{$C H W A-D(n=9)$} & \multicolumn{2}{|c|}{$F A P(n=45)$} & \multicolumn{2}{|c|}{$H B O C(n=24)$} & \multirow[b]{2}{*}{$F$} & \multirow[b]{2}{*}{$d f$} & \multirow[b]{2}{*}{$p$} \\
\hline & Mean & $S D$ & Mean & $S D$ & Mean & $S D$ & Mean & $S D$ & & & \\
\hline \multirow{5}{*}{$\begin{array}{l}\text { Intrusion } \\
\text { Avoidance }\end{array}$} & 9.3 & 1.3 & 7.3 & 1.1 & 4.0 & 1.6 & 6.3 & 1.3 & 101.45 & 3,115 & $\ll 0.001$ \\
\hline & 8.1 & 1.1 & 7.6 & 0.6 & 4.4 & 1.4 & 4.4 & 1.3 & 82.22 & 3,115 & $\ll 0.001$ \\
\hline & \multicolumn{11}{|c|}{ Partner } \\
\hline & \multicolumn{2}{|c|}{$H D(n=32)$} & \multicolumn{2}{|c|}{$H C H W A-D(n=7)$} & \multicolumn{2}{|c|}{$F A P(n=18)$} & \multicolumn{2}{|c|}{$H B O C(n=8)$} & & & \\
\hline & Mean & $S D$ & Mean & $S D$ & Mean & $S D$ & $\overline{M e a n}$ & $S D$ & $F$ & $d f$ & $p$ \\
\hline Intrusion & 4.8 & 0.7 & 3.8 & 0.4 & 3.3 & 0.7 & 1.4 & 0.6 & 105.86 & 3,70 & $\ll 0.001$ \\
\hline Avoidance & 4.6 & 0.9 & 4.6 & 0.5 & 3.3 & 0.9 & 1.3 & 0.7 & 66.93 & 3,71 & $\ll 0.001$ \\
\hline
\end{tabular}

life, and whether they would doubt the test result when proven not to be a gene carrier. An adjusted version of the questionnaire was given to the partners, which covered the partners' experiences with the disorder in the family of his/her spouse/partner at risk.

The questionnaire was modified from the Dutch HD study to accommodate both the neurodegenerative disorders and the cancer syndromes. $^{47}$ (A translation of the questionnaire used in this study in available upon request.) Each answer was scored separately and no total scores were calculated.

Additionally, biographical data, including gender, age, marital status, employment status, number of children, level of education, and religious practice were assessed.

Table 4 Experience with the disorder as a predictor of psychological distress: intrusion and avoidance

\begin{tabular}{|c|c|c|c|c|}
\hline \multirow[b]{3}{*}{ Experience } & \multicolumn{4}{|l|}{ At risk } \\
\hline & \multirow{2}{*}{$\frac{\text { Intrusion }}{B t}$} & \multirow[b]{2}{*}{$p$} & \multicolumn{2}{|c|}{ Avoidance } \\
\hline & & & $B$ & $p$ \\
\hline \multirow{3}{*}{$\begin{array}{l}\text { Report of specific disease characteristics in } \\
\text { affected parent } \\
\text { Report of specific disease characteristics in } \\
\text { affected family members } \\
\text { Emotional report of the impact of the } \\
\text { disorder on one's life up to now (eg shame, } \\
\text { fear, anger) }\end{array}$} & 0.19 & 0.04 & - & - \\
\hline & 0.19 & 0.05 & - & - \\
\hline & 0.21 & 0.02 & 0.26 & 0.005 \\
\hline \multirow[b]{3}{*}{ Experience } & \multicolumn{4}{|l|}{ Partner } \\
\hline & \multicolumn{2}{|l|}{ Intrusion } & \multicolumn{2}{|c|}{ Avoidance } \\
\hline & $B$ & $p$ & $B$ & $p$ \\
\hline $\begin{array}{l}\text { Emotional report of the impact of the } \\
\text { disorder on one's life up to now (eg shame, } \\
\text { fear, anger) }\end{array}$ & 0.40 & $\ll 0.001$ & 0.27 & 0.03 \\
\hline
\end{tabular}

^Experience was assessed with section A of the Attitude Questionnaire.

$+B=$ standardised regression coefficient.
STATISTICAL ANALYSES

All data analyses were obtained using SPSS for Windows, version 6.1. To examine whether the four groups of subjects at risk for, respectively, HD, HCHWA-D, FAP, and HBOC differed, one way analysis for continuous data was applied. Scores were adjusted for gender and age, so that findings could be subscribed to the type of disorder (table 3). Chi-square test was used for nominal data, like the biographical data in table 2 . When the testing was statistically significant, post hoc comparisons for continuous data according to Scheffés S method were done between the four genetic disorders in order to establish which group of participants differed from which. For nominal data Bonferoni's procedures were applied. In order to estimate the association between attitudinal characteristics (for example, experience with the disease, motivation to be tested, and the expected impact of the test result) and the two subscales of the IES, intrusion and avoidance respectively, the standardised regression coefficient (B) was estimated (tables 4,5 , and 6 ). The level of statistical significance was set at 0.05 , two sided.

\section{Results}

DESCRIPTIVE

General characteristics of the study population are given in table 2 . We found that participants at risk for FAP were younger than those at risk for HD and HBOC, using Scheffé's $S$ method to differentiate between the four groups. There was no significant difference between the groups of participants concerning the age they learned about the hereditary nature of the disorder in the family. The participants at risk for FAP were younger when they learned about their own risk than those at risk for HBOC. This is, however, over the age of 12 years when 
Table 5 The motivation to be tested ${ }^{\star}$

\begin{tabular}{ll}
\hline & Cited byt \\
\hline $\begin{array}{ll}\text { Considerations to take the test } \\
\text { The burden of being at risk }\end{array}$ & $62 \%$ \\
To know for the children & $35 \%$ \\
$\begin{array}{l}\text { For preventive treatment or check up } \\
\text { To plan the future }\end{array}$ & $16 \%$ \\
$\begin{array}{l}\text { Regarding the wish to have children } \\
\text { Considerations against testing }\end{array}$ & $13 \%$ \\
$\begin{array}{l}\text { Expected adverse reactions of knowing } \\
\quad \text { oneself to be a gene carrier }\end{array}$ & $11.5 \%$ \\
$\begin{array}{l}\text { New uncertainties after knowing oneself } \\
\quad \text { to be a gene carrier }\end{array}$ & $34 \%$ \\
$\begin{array}{l}\text { No gain by knowing } \\
\text { Could think of no reason against testing }\end{array}$ & $5 \%$ \\
\end{tabular}

^Motivation was assessed with section B of the Attitude Questionnaire.

†Percentages of the total population.

screening is first advised for participants at risk for FAP. Participants at risk for FAP are younger, more often single, and without children.

DIFFERENCE IN PSYCHOLOGICAL DISTRESS IN THE FOUR GROUPS AT RISK AND PARTNERS

Table 3 presents mean scores on the two subscales of the IES, intrusion and avoidance, for participants at risk for HD, HCHWA-D, FAP, and HBOC and their partners. The group differences were tested for significant differences.

\section{Participants at risk}

A statistically significant difference $(\mathrm{p}<0.001)$ was found between the four groups of participants for both subscales of the IES. Concerning intrusion, we found, using Scheffé's S method, that participants at risk for HD reported more intrusion than the other three groups at risk (HCHWA-D, HBOC, and FAP). Subjects at risk for FAP reported less intrusion than the others three groups at risk (HD, HCHWA-D, and HBOC). Concerning avoidance, we found that participants at risk for the neurodegenerative disorders (HD and HCHWA-D) reported more avoidance than those at risk for the cancer syndromes (FAP and $\mathrm{HBOC}$ ).

\section{Partners}

A statistically significant difference $(p<0.001)$ was also found for the four groups of partners for both subscales of the IES. We found, using Scheffe's $S$ method, that partners of participants at risk for HD reported more intrusion than the other partners (HCHWA-D, HBOC, and FAP). Partners of participants at risk for

Table 6 The motivation to be tested as predictor of psychological distress: intrusion and avoidance*

\begin{tabular}{lllllll}
\hline & \multicolumn{2}{c}{ Intrusion } & & \multicolumn{2}{c}{ Avoidance } \\
\cline { 2 - 3 } \cline { 5 - 7 } & $B t$ & $p$ & & $B$ & $p$ \\
\hline $\begin{array}{l}\text { Considerations not to take } \\
\text { the test }\end{array}$ & & & & & \\
$\begin{array}{l}\text { Psychological burden of } \\
\text { knowing oneself to be at }\end{array}$ & & & & & & \\
$\quad$ risk & 0.30 & $\ll 0.001$ & & 0.29 & 0.002 \\
No idea & -0.18 & 0.05 & -0.28 & 0.05 \\
\hline
\end{tabular}

${ }^{\star}$ Motivation was assessed with section B of the Attitude Questionnaire.

$+B=s t a n d a r d i s e d$ regression coefficient.
HBOC reported less intrusion than the other partners (HD, HCHWA-D, and FAP), and also less avoidance than the other partners (HD, HCHWA-D, and FAP). The partners of participants at risk for the neurodegenerative disorders (HD and HCHWA-D) reported more avoidance than those at risk for the cancer syndromes (FAP and HBOC).

In order to establish whether the previous experiences with the disease were associated with psychological distress, we conducted a regression analysis with intrusion and avoidance as the dependent variable for the participants at risk and the partners, respectively, and the experiences with the disorder (section A of the AQ), age, and the specific disorder as potential predictor variables. The same regression analyses were conducted with, respectively, the motives for and against testing (section $\mathrm{B}$ of the $\mathrm{AQ}$ ) and the expectations about the impact of the test result (section $C$ of the $A Q$ ) as potential predictor variables. Only the statistically significant results are presented in tables 4,6 , and 7 .

EXPERIENCE WITH THE DISORDER AS PREDICTOR OF PSYCHOLOGICAL DISTRESS (TABLE 4) Participants at risk

It was found that intrusion was associated with key experiences with the disease and by emotional descriptions of the impact of the disease on the participant's life so far. Participants who reported disease specific key experiences such as: "seeing Mum and Dad cleaning the bed in the middle of the night" (FAP), "hearing people laughing at and scorning the affected parent for drunken-like behaviour", "seeing Father tied to his chair" (HD), "Mother in her hospital bed unable to use her arm", or "Mother having a fat belly and always in pain" (HBOC), and "parent rubbing his head all the time because of headaches" (HCHWA-D), had high levels of intrusion. Test candidates who described the impact of the disorder on their personal life in emotional terms (for example, shame, fear, or anger) also had higher intrusion and avoidance levels. Neither age nor the type of disorder was associated with psychological distress.

\section{Partners}

Partners who described the impact of the disease on their own life in emotional terms (for example, shame, fear, or anger) had higher scores on both intrusion and avoidance.

MOTIVATION TO BE TESTED AS PREDICTOR OF PSYCHOLOGICAL DISTRESS

Commonly cited considerations for and against testing are presented in table 5 .

\section{Participants at risk (table 6)}

None of the motives for undergoing testing was associated with psychological distress. However, participants who regarded the negative implications of knowing oneself to be a gene carrier as a possible reason against testing had high intrusion and avoidance levels. Those who could not think of any considerations against 
Table 7 The expected impact of test result as a predictor of psychological distress: intrusion and avoidance*

\begin{tabular}{|c|c|c|c|c|}
\hline \multirow[b]{3}{*}{ Future expectations } & \multicolumn{4}{|c|}{ At risk } \\
\hline & \multicolumn{2}{|c|}{ Intrusion } & \multicolumn{2}{|c|}{ Avoidance } \\
\hline & $B t$ & $p$ & $B$ & $p$ \\
\hline \multicolumn{5}{|l|}{ When proven to be a gene carrier } \\
\hline Life becomes less worthwhile & 0.19 & 0.04 & 0.40 & $\ll 0.001$ \\
\hline Problems increase & - & - & 0.18 & 0.05 \\
\hline Try to avoid family & 0.17 & 0.04 & 0.22 & 0.02 \\
\hline Become depressive & 0.30 & $\ll 0.001$ & 0.26 & 0.005 \\
\hline Has not that much effect $\neq$ & -0.30 & $\ll 0.001$ & -0.20 & 0.04 \\
\hline Anticipate the future $\neq$ & 0.21 & 0.03 & - & - \\
\hline \multicolumn{5}{|l|}{ When proven to be a non-carrier } \\
\hline Life becomes more worthwhile & 0.28 & 0.002 & 0.31 & $\ll 0.001$ \\
\hline Problems decrease & 0.34 & $\ll 0.001$ & 0.28 & 0.003 \\
\hline Be able to plan the future better & 0.24 & 0.02 & 0.24 & 0.02 \\
\hline Mood improvement & 0.43 & $\ll 0.001$ & 0.37 & $\ll 0.001$ \\
\hline Experience reliefł & 0.35 & $\ll 0.001$ & 0.22 & 0.02 \\
\hline \multirow[t]{4}{*}{ Doubt the test result } & 0.18 & 0.05 & - & - \\
\hline & \multicolumn{4}{|c|}{ Partner } \\
\hline & \multicolumn{2}{|c|}{ Intrusion } & \multicolumn{2}{|c|}{ Avoidance } \\
\hline & $B t$ & $p$ & $B$ & $p$ \\
\hline \multicolumn{5}{|c|}{ When partner proves to be a gene carrier } \\
\hline Problems increase & 0.28 & 0.03 & - & - \\
\hline Try to avoid family & 0.25 & 0.03 & - & - \\
\hline Doubt the test result & 0.22 & 0.05 & 0.24 & 0.04 \\
\hline \multicolumn{5}{|c|}{ When partner proves to be a non-carrier } \\
\hline Try to avoid family & 0.25 & 0.03 & - & - \\
\hline Nothing changes $\ddagger$ & -0.23 & 0.05 & -0.31 & 0.009 \\
\hline Think everything over $\ddagger$ & 0.35 & 0.003 & - & - \\
\hline
\end{tabular}

*The expected impact was assessed with section C of the Attitude Questionnaire. †Standardised regression coefficient.

$\ddagger$ Answer to open ended question.

uptake had low distress scores on both intrusion and avoidance. Neither age nor the type of disorder was associated with psychological distress.

\section{Partners}

No statistically significant results were found.

EXPECTED IMPACT OF THE TEST RESULT AS

PREDICTOR OF PSYCHOLOGICAL DISTRESS

(TABLE 7)

Participants at risk

Those who reported that knowing oneself to be a gene carrier would not affect their personal life had the lowest scores on intrusion and avoidance. Test candidates who thought that knowing oneself to be a gene carrier allowed them to anticipate the future better reported the most intrusion. Those who thought that confirmation of gene carriership would increase their problems reported more avoidance.

Participants who acknowledged that knowing oneself not to be a gene carrier would affect their lives in a positive way, resulting in better mood and relief, and allowing them to plan the future better, reported more intrusion. However, high intrusion was also associated with the expectation that an exclusion of gene carriership could be doubted. Neither age nor the type of disorder was associated with psychological distress.

\section{Partners}

In the partner groups, high levels of psychological distress were associated with the strong belief that confirmation of gene carriership could be doubted. Partners with high intrusion were those who expected that problems might increase and that such a result would lead to avoiding the relatives of the identified gene carrier.

Partners with high intrusion also expected that exclusion of gene carriership might lead to avoiding the non-carrier's relatives. Those who would re-evaluate their personal situation reported the highest intrusion. Partners who believed that an exclusion of gene carriership would have no influence on their life had the lowest intrusion and avoidance scores.

\section{Discussion}

INTERPRETATION OF THE REPORTED

PSYCHOLOGICAL DISTRESS

To introduce the discussion of the findings, we describe the possible implications of high and low distress scores. The reported psychological distress is measured as intrusively experienced ideas, images, feelings, or bad dreams (intrusion) and the consciously recognised avoidance of certain ideas, feelings, or situations (avoidance). The resulting score implies more than that people with high scores are doing "badly" and people with low scores are doing "well". It was in fact the intolerable psychological burden of being at risk that was the prime reason for uptake of the predictive test for $\mathrm{HD}$, as mentioned previously, ${ }^{14232526}$ and these participants were considered to have considerable mental resources. ${ }^{2021}$ Moreover, the well being of $\mathrm{HD}$ carriers had improved one year after testing. ${ }^{50}$ High intrusion levels may reflect great suffering from being at risk, but also worrying as a preparation for the test result. ${ }^{40} \mathrm{~A}$ follow up study on effects of predictive testing for $\mathrm{HD}^{51}$ reported that high avoidance levels predicted post-test feelings of hopelessness, whereas high pre-test intrusion levels did not. Thus, high pre-test intrusion scores could also be valued positively and be seen as indicative of an adjustment process.

It should be noted that low scores on "mental health scales" can reflect opposite conditions. Low scores usually indicate good psychological health; on the other hand distress may be present, but denied in order to "maintain an illusion of mental health".52 A participant at risk (or a partner) may try to convince themselves that there is no reason to worry and report very low distress scores, while in fact they are emotionally affected by the predictive test.

\section{MAJOR FINDINGS \\ Difference in psychological distress in the four groups at risk and partners}

Interestingly, subjects at risk for $\mathrm{HD}$ reported the highest levels of distress (high intrusion and avoidance scores), while those at risk for FAP reported the lowest levels of distress (low intrusion and avoidance scores). No treatment options are available for the first group, whereas there are (drastic) options for people at risk for FAP. Also the long and very incapacitating course of $\mathrm{HD}$ will influence the pre-test distress. The perception of immediate risk may also differ among the various participants. Those at risk for HD, HCHWA-D, and 
HBOC are within the average age for disease occurrence in gene carriers; FAP participants are mostly older than the average age at onset. ${ }^{53-56}$ This could explain why participants at risk for FAP report significantly less intrusion than the other three groups at risk.

HD imposes a considerable burden on the partner, ${ }^{32}$ especially when there are offspring. ${ }^{35}$ Partners of people at risk for HD reported significantly higher levels of distress than the other partners. Unexpectedly, we found that partners of participants at risk for HBOC reported significantly lower psychological distress than all the other partners. Six out of eight partners in the HBOC sample are male. This led us to speculate whether these men were just undisturbed by the predictive test, or whether other psychological mechanisms were at work (for example, defensive denial). Breast cancer is reported to have a significant impact on the woman's partner. ${ }^{57}$ Further studies in a larger sample may show how partners of women at risk for HBOC cope with the impending threat of breast and ovarian cancer and the treatment options for their wife.

Although in the present study a profound difference was found in reported psychological distress when comparing the four groups of disorders, there was no indication that the type of disease or age predicted pre-test psychological distress in the additional analyses. We examined whether experience with the disorder, motivation to be tested, and the expected impact of the test result could predict distress. To a certain extent they did, as discussed below. Other characteristics of the population (for example, educational level, cultural identity, religious faith, thoughts and beliefs about their luck and destiny, other perceived dangers in life) were not analysed, although these factors are obviously relevant in coping with personal risks and test results.

\section{Experience with the disorder as predictor of} psychological distress

A clear recollection of symptoms observed by the participant in the affected parent/relatives predicted high levels of intrusion. Also, when participants at risk and partners described the impact of the disease on their life in emotional terms (such as, anger, fear, and shame) an association was found with high levels of both intrusion and avoidance. They tried to distract themselves from ideas, images, and feelings they intrusively experience. This pattern may reflect problems in adjusting to the effects of the disease on their life and needs to be paid attention to.

\section{Motivation to be tested as predictor of psychological distress}

As previously described for neurodegenerative disorders, ${ }^{14}{ }^{23} 25-27$ we found that the main reasons for testing were intolerable psychological burden of being at risk, giving information to offspring and relatives, and planning future life and family. Only $16 \%$ of all participants (while $57 \%$ were at risk for the hereditary cancer syndromes) stated that preventive treatment or check up was their reason for testing.
Interestingly, those who were worried about the possible adverse effects of knowing oneself to be a gene carrier and who considered it as a possible reason not to take the test reported the highest psychological distress (high intrusion and avoidance scores), yet they all took the test. This "worrying" can be considered as preparation for the test result. The possible adverse effects of being a gene carrier are considered and acknowledged. ${ }^{40}$ It is important, however, to enable the participant to discuss his/her worries in order to demystify fears sometimes rooted in childhood experiences with the disease. Those who had no reasons against the test reported little or no psychological distress. Experience with HD test candidates have shown that some participants, who had gone through lengthy considerations, are not willing to undergo all the ramifications of pre-test counselling. ${ }^{35}$ They were determined to have the test and were anxious at that stage about re-experiencing previous ambivalence. The reluctance to consider reasons against testing may reflect a denial-avoidance behaviour to minimise the full impact. ${ }^{52}$ The mechanisms of defensive denial which enable test candidates to ward off anxieties should be respected as his/her way of dealing with threat; this should be handled carefully but with acknowledgement of the underlying fear.

\section{Expected impact of the test result as predictor of psychological distress}

In general, the anticipation of adverse effects of becoming identified as a gene carrier was associated with high levels of intrusion and avoidance (all participants wanted to be tested). An expected increase of personal difficulties after confirmation of gene carriership was associated with high avoidance but not with intrusion. High pre-test avoidance was earlier found to be associated with a pessimistic post-test attitude. ${ }^{35}$ The possible adverse effects of being a gene carrier are kept away instead of being worked through, and this "lack of worrying" can be considered to lead to being less prepared. ${ }^{40}$

Preparation for the future was associated with high intrusion but not with avoidance, which supports our hypothesis that such behaviour reflects worrying. ${ }^{40}$ Those who expected their life to become better/easier when proven to be a non-carrier reported high distress (high intrusion and avoidance scores). High expectations about exclusion of gene carriership reflects the difficulties experienced in dealing with the threat of the disease. Such an expected outcome leads to vulnerability given that the test outcome is unsure. It also reflects an underestimation of the possible adverse effects of exclusion of gene carriership, as was described in several studies on HD. ${ }^{29}{ }^{35} 36$ Partners who would doubt a diagnosis of gene carriership in the at risk subject reported high distress (high intrusion and avoidance scores). This is in accordance with the finding that partners of identified carriers felt burdened by the distressing prospect. ${ }^{32-36}$ 
AREAS FOR FURTHER STUDY

This is the first comparative study of predictive testing for hereditary neurodegenerative and cancer syndromes in two centres. The relatively small numbers in some groups is a limitation. The higher number of participants at risk for FAP and HBOC opting against the psychological protocol reflect a possible specific attitude in this group. They were determined to take the test without further psychological assessment, since they experienced their choice as a purely medical decision. The HBOC group consisted of some individual subjects and the first three Dutch families that could be tested. This might introduce some bias by potential extensive attention from the researchers. ${ }^{13} 50$ Future analysis of test candidates with and without psychological evaluation and support, using self-reporting as well as observer reports, is indicated. ${ }^{52}$

Furthermore, in future follow up research on predictive testing for late onset genetic disorders, the IES as a measure of psychological distress may be standardised for specific groups with high personal risk of developing a specific disease.

\section{Conclusions}

Candidates at risk for the four disorders differed from each other in the reported distress, as did the partners. The type of disorder, however, was not found to predict the reported distress. Aspects of the experiences with the disease, the motivation to be tested, and the expected impact of the test result were associated with the reported distress. However, other more sociodemographic characteristics (for example, educational level, cultural identity, religious faith) were not taken into account; these may be associated with the reported distress and should therefore be taken into account in genetic counselling.

For clinical practice it is important to be aware that those responding to the subject (remembering affected relatives, preparing for the future) or those who may seem preoccupied or even overly involved might in fact be engaged in preparing themselves for the test result. Participants at risk may be very upset when recounting the impact of the disease and their reasons for being tested, which may worry the healthcare professional. However, professionals must be able to value positively these "states of mind" as they may be indicative of psychological strength and adequate preparation for the test result. Those who refrain from discussing the implications of the test (seeing no reason not to take the test, reporting little or no distress) may be unable to face all possible outcomes and need to convince themselves that everything is under control. However, such apparent strength may lead to underdiagnosis of distress, while some may need specific attention. In short, people with high distress scores may be actively dealing with the problem, while people with low distress scores might (as yet) be unable to face the problems.

It is important to identify and respect the chosen strategy of coping with threat. Additional research is needed to gain more understanding of the relationship between the (un)reported psychological distress and the preparation for, and later adaptation to, the test result. Only then will it be possible to decide upon the appropriate uses to which predictive testing may be put and about any controls that might be deemed necessary. ${ }^{11}$

This research was supported by NWO grant 96010803 to the first author. The authors are very grateful to the people at risk and their partners who have participated in this study.

1 The Huntington's Disease Collaborative Research Group. A novel gene containing a trinucleotide repeat that is expanded and unstable on Huntington's disease chromosomes. Cell 1993;72:971-83.

2 Brook JD, McCurrach ME, Harley HG, et al. Molecular basis of myotonic dystrophy: expansion of a trinucleotide (CTG) repeat at the 3 ' end of a transcript encoding a pro(CTG) repeat at the 3 end of a transcript encoding

3 Bird TD. Familial Alzheimer's disease. Ann Neurol 1994;36: 335-6.

4 Haltia M, Viitanen M, Sulkava R, et al. Chromosome 14-encoded Alzheimer's disease: genetic and clinicopathological description. Ann Neurol 1994;36:362-7.

5 Bakker E, van Broeckhoven C, Haan J, et al. DNA diagnosis for hereditary cerebral hemorrhage with amyloidosis for hereditary cerebral hemorrhage with am
(Dutch type). Am f Hum Genet 1991;49:518-21.

6 Wooster R, Neuhausen SL, Mangion J, et al. Localization of a breast cancer susceptibility gene, BRCA2, to chromosome 13q12-13. Science 1994;265:2088-90.

7 Miki Y, Swensen J, Shattuck-Eidens D, et al. A strong candidate for the breast and ovarian cancer susceptibility gene BRCA1. Science 1994;266:66-71.

8 Kinzler KW, Nilbert MC, Su LK, et al. Identification of FAP locus genes from chromosome 5q21. Science 1991;253: 661-5.

9 Groden J, Thliveris A, Samowitz W, et al. Identification and characterization of the familial adenomatous polyposis coli gene. Cell 1991;66:589-600.

10 Wijnen J, Vasen H, Khan PM, et al. Seven new mutations in hMSH2, an HNPCC gene, identified by denaturing gradient-gel electrophoresis. Am f Hum Genet 1995;56: 1060-6.

11 Davison C. Predictive genetics: the cultural implications of supplying probable futures. In: Marteau TM, Richards MPM, eds. The troubled helix; social and psychological impliMPM, eds. The troubled helix; social and psychological impli-
cations of the new human genetics. Cambridge: Cambridge University Press, 1996.

12 Harper P. Ethical issues in genetic testing for Huntington's disease: lessons for the study of familial cancers. Dis Markers 1992;10:189-93.

13 Ponder M, Green JM. BRCAl testing: some issues in moving from research to service. Psycho-Oncology 1996;5:22332 .

14 Craufurd D, Dodge A, Kerzin-Storrar L, Harris R. Uptake of presymptomatic predictive testing for Huntington's disease. Lancet 1989;ii:603-5.

15 Tibben A, Niermeijer MF, Roos RAC, et al. Understanding the low uptake of presymptomatic DNA testing for Huntington's disease. Lancet 1992;340:1416.

16 Quaid KA, Morris M. Reluctance to undergo predictive testing: the case of Huntington disease. Am 7 Med Genet 1993;45:41-5.

17 Lerman C, Narod S, Schulman K, et al. BRCA1 testing in families with hereditary breast-ovarian cancer. $\mathfrak{f} A M A$ families with her

18 Maat-Kievit JA. Erfelijkheidsvoorlichting en de ziekte van Huntington. (Genetic information and Huntington's disease). In: Tibben A, Beemer FA, Brunner HG, eds. Presymptomatische DNA-diagnostiek voor erfelijke, later in het leven optredende, ziekten. Rotterdam: Bureau PAOG, Erasmus Universiteit Rotterdam, 1996.

19 Bornebroek M, Haan J, van Buchem MA, et al. White matter lesions and cognitive deterioration in presymptomatic carriers of the amyloid precursor gene codon 693 carriers of the amyloid precursor

20 Bloch M, Adam S, Wiggins S, Huggins M, Hayden MR. Predictive testing for Huntington disease in Canada: the experience of those receiving an increased risk. $A m \mathcal{F} M e d$ Genet 1992;42:499-507.

21 Codori AM, Hanson R, Brandt J. Self-selection in predictive testing for Huntington's disease. Am $\mathcal{F}$ Med Genet 1994;54: 167-73.

22 van der Steenstraten IM, Tibben A, Roos RAC, van de Kamp JJP, Niermeijer MF. Predictive testing for Huntington disease: nonparticipants compared with participants in the Dutch program. Am f Hum Genet 1994;55:618-25.

23 Bloch M, Fahy M, Fox S, Hayden MR. Predictive testing for Huntington disease. II. Demographic characteristics, lifestyle patterns, attitudes, and psychosocial assessments of style patterns, attitudes, and psychosocial assessments of
the first fifty-one test candidates. Am $f$ Med Genet 1989;32: the first

24 Craufurd D, Harris R. Predictive testing for Huntington's disease. $B M \mathcal{F}$ 1989;298:892 
25 Meissen GJ, Mastromauro CA, Kiely DK, McNamara DS Myers RH. Understanding the decision to take the predictive test for Huntington disease. Am 7 Med Genet 1991;39. 404-10.

26 Simpson SA, Besson J, Alexander D, Allan K, Johnston AW. One hundred requests for predictive testing for Huntington's disease. Clin Genet 1992;41:326-30.

27 Tibben A, Stevens M, van der Wert GMWR, Niermeijer MF, van Duijn CM, van Swieten JC. Preparing for pre van Duifn CM, vating for early onset Alzheim presymptomatic DNA testing for early onset Alzheimer's disease/cerebral henet 1997;34:63-72.

28 Watson M, Murday V, Lloyd S, Ponder B, Averill D, Eeles R. Genetic testing in breast/ovarian cancer (BRCA1) families. Lancet 1995;346:583.

29 Huggins $M$, Bloch $M$, Wiggins $S$, et al. Predictive testing for Huntington disease in Canada: adverse effects an unexpected results in those receiving a decreased risk. $A m$ fMed Genet 1992;42:508-15.

30 Marteau TM, Richards MPM. The troubled helix; social and psychological implications of the new human genetics. Cambridge: Cambridge University Press, 1996.

31 Dudok de Wit AC, Tibben A, Frets PG, et al. BRCA1 in the family; a case description of the psychological interaction. Am $\mathcal{F}$ Med Genet (in press).

32 Evers-Kiebooms G, Swerts A, Van Den Berghe H. Partners of Huntington patients: implications of the disease and of Huntington patients: implications of the disease and opinions about predictive

33 Kessler S. Forgotten person in the Huntington disease fam ily. $A m \mathcal{F}$ Med Genet 1993;48:145-50.

34 Quaid KA, Wesson MK. Exploration of the effects of predictive testing for Huntington disease on intimate relationships. Am $\mathcal{F}$ Med Genet 1995;57:46-51.

35 Tibben A, Frets PG, van de Kamp JJP, et al. On attitudes and appreciation 6 months after predictive DNA testing for Huntington disease in the Dutch program. Am f Med Genet 1993;48:103-11.

36 Tibben A, Timman R, Bannink EC, Duivenvoorden HJ. 3-year follow-up after presymptomatic testing for Huntington disease in tested individuals and partners. Health ton disease in tested

37 Horowitz MJ. Intrusive and repetitive thoughts after experimental stress. Arch Gen Psychiatry 1975;32:1457-63.

38 Horowitz MJ, Wilner N, Kaltreider N, Alvarez W. Signs and symptoms of posttraumatic stress disorder. Arch Gen Psychiatry 1980;37:85-92

39 Horowitz MJ, Wilner N, Alvarez W. Impact of Event Scale: a measure of subjective stress. Psychosom Med 1979;41:209 18.

40 Janis IL, Mahl GF, Kagan J, Holt RR. Personality; dynamics, development and assessment. New York: Harcourt, Brace \& World, 1969.

41 De Rooij KE, De Koning Gans PA, Skraastad MI, et al. Dynamic mutation in Dutch Huntington's disease patients: increased paternal repeat instability extending to within the normal size range. 7 Med Genet 1993;30:996-1002.

42 De Rooij KE, de Koning Gans PA, Losekoot M, et al. Borderline repeat expansion in Huntington's disease. Lancet 1993:342:1491-2.

43 Fodde R, van der Luijt R, Wijnen J, et al. Eight novel inactivating germ line mutations at the APC gene identified by vating germ line mutations at the APC gene identifics $1992 ; 13$ : 1162-8.
44 van der Luijt R, Khan PM, Vasen $\mathrm{H}$, et al. Rapid detection of translation-terminating mutations at the adenomatous polyposis coli (APC) gene by direct protein truncation test. Genomics 1994;20:1-4.

45 Couch FJ, Weber BL. Mutations and polymorphisms in the familial early onset breast cancer (BRCA1) gene. Hum Mutat 1996;8:8-18.

46 Hogervorst FB, Cornelis RS, Bout M, et al. Rapid detection of BRCA1 mutations by the protein truncation test. $\mathrm{Na}$ Genet 1995;10:208-12.

47 Tibben A, Frets PG, van de Kamp JJP, et al. Presymptomatic DNA-testing for Huntington disease: pretest attitudes and expectations of applicants and their partners in the Dutch program. Am f Med Genet 1993;48:10-16.

48 Zilberg NJ, Weiss DS, Horowitz MJ. Impact of Event Scale a cross-validation study and some empirical evidence supporting a conceptual model of stress response syndromes. $\mathcal{F}$ Cons Clin Psychol 1982;50:407-14.

49 Schwarzwald J, Solomon Z, Weisenberg M, Mikulincer M. Validation of the impact of event scale for psychological sequelae of combat. F Cons Clin Psychol 1987;55:251-6.

50 Wiggins S, Whyte P, Huggins $M$, et al. The psychologica consequences of predictive testing for Huntington's disease. Canadian collaborative study of predictive testing. N Engl f Med 1992;327:1401-5.

51 Tibben A, Duivenvoorden HJ, Vegter-van der Vlis M, et al. Presymptomatic DNA testing for Huntington disease: identifying the need for psychological intervention. $A m \mathcal{F}$ Med Genet 1993;48:137-44.

52 Shedler J, Mayman M, Manis $M$. The illusion of mental health. Am Psychol 1993;48:1117-31.

53 Roos RAC, Vegter-van der Vlis M, Hermans J, et al. Age at onset in Huntington's disease: effect of line of inheritance and patient's sex. F Med Genet i 991;28:515-19.

54 Haan J, Roos RAC, Briet PE, Herpers MJ, Luyendijk W, Bots GT. Hereditary cerebral hemorrhage with amyloidosis-Dutch type. Research group hereditary cerebral amyloid angiopathy. Clin Neurol Neurosurg 1989;91. 285-90.

55 Jagelman D. The expanding spectrum of familial adenomatous polyposis. Perspect Colon Rectal Surg 1988;1:30-46.

56 Cornelis RS, Vasen HF, Meijers-Heijboer H, et al. Age at diagnosis as an indicator of eligibility for BRCA1 DNA testing in familial breast cancer. Hum Genet 1995;95:53944.

57 Zahlis EH, Shands ME. Breast cancer: demands of the illness on the patient's partner. $\mathcal{F}$ Psychosoc Oncol 1991;9: 75-93.

58 Harper PS. Huntington's disease. London: Saunders, 1991.

59 Easton DF, Bishop DT, Ford D, Crockford GP. Genetic linkage analysis in familial breast and ovarian cancer: linkage analysis in familial The Breast Cancer Linkage Consortium. Am f Hum Genet 1993;52:678-701.

60 Easton DF, Ford D, Bishop DT. Breast and ovarian cance incidence in BRCA1-mutation carriers. Breast Cance Linkage Consortium. Am f Hum Genet 1995;56:265-71.

61 Ford D, Easton DF, Bishop DT, Narod SA, Goldgar DE. Risks of cancer in BRCA1-mutation carriers. Breast Cancer Linkage Consortium. Lancet 1994;343:692-5. 